\title{
Top priorities in information systems: The South African perspective
}

\author{
Jonathan Miller and Leyland F. Pitt \\ Graduate School of Business, University of Cape Town, Rondebosch 7700, Republic of South Africa
}

Received 12 June 1990; accepted 27 August 1990

\begin{abstract}
In this article findings of a three-round Delphi study concerning key issues in information systems (IS) are presented, as perceived by a group of South African information systems managers. Some adaptations to the Delphi method were made, and these are described. The ten most important issues are identified, and these are categorized. It emerges that most are externally orientated and deal with the relationship between IS and the enterprise. The implications for information systems practitioners, academics, consultants and professional bodies are discussed.

In hierdie artikel word die bevindinge van 'n drie-rondte Delphi-studie na sleutelvraagstukke in inligtingstelsels, soos waargeneem deur 'n groep Suid-Afrikaanse inligtingstelselbestuurders, gerapporteer. Enkele aanpassings van die Delphi-metode is gedoen en word hier beskryf. Die tien belangrikste vraagstukke word gëdentifiseer en gekategoriseer. Dit blyk dat die oorsprong van hierdie viaagstukke oorwegend ekstern van aard is en verband hou met die wisselwerking tussen inligtingstelsels en die onderneming. Die implikasies vir inligtingstelselpraktisyns, akademici, konsultante en beroepsliggame word bespreek.
\end{abstract}

\section{Introduction}

Information Systems (IS) managers face a difficult task because they operate in a chasm between information technology and senior management. They must be able to interpret trends in information technology, assess the impact of these on the organisation, and decide which technologies to adopt. Simultaneously, they have to link the IS plan to corporate objectives so that the IS department serves the needs of the enterprise. Deciding on the proportion of resources allocated to technical or managerial problems is an important facet of the IS manager's job. As all IS executives face similar problems, an awareness of the issues that are of most concem to their peers can be of assistance to individual managers. Those whose perceptions of key matters in their organisation are different from their peers need to consider why this is so. Are they concentrating on the wrong issues, or are there some unique features in their organisation? Conversely, those who find that they hold common views with their peers may draw some comfort, however cold, from at least knowing they are not alone.

If IS academics, consultants, professional societies, and researchers are to serve the IS community effectively, they must be aware of the key issues facing IS managers. Academics need information on key concerns to develop graduates with the necessary skills to solve these issues. Consultants, who play a key role in IS because they can accelerate the transfer of new skills and technology to IS practitioners, will be more effective if they know the areas in which their clients need the most assistance. Professional societies serve the IS community by arranging conferences, sponsoring guest lectures, and disseminating information through their publications. Successful performance of these tasks requires that professional societies are in tune with the needs of their members. Therefore, it is important that the South African IS community be aware of those issues that are judged by its leading practitioners to be of critical concern.

In order to provide information concerning the key IS issues, a three-round Delphi study was conducted with IS managers in major South African organisations in the latter half of 1989. The purpose of the study was to determine, in order of importance, the most critical issues facing South African IS executives over the next three to five years. The investigation was based upon the approach used by the Management Information Systems (MIS) research centre (MISRC) at the University of Minnesota where two previous key issue surveys have been conducted (Dickson, Leitheiser, Wetherbe, and Nechis, 1984; Brancheau and Wetherbe, 1987) and a third is currently underway. A similar study has been conducted in Australia by Watson (1989).

\section{Method}

Delphi, a group decision-making process, is particularly useful for assessing the judgement of a large, dispersed group of experts (Bass, 1983). A typical Delphi study starts with an open-ended questionnaire that solicits opinions on the issues associated with the study. Succeeding rounds of the study feed back the previous round's results so that participants can revise their judgements. In theory, the Delphi process should continue until the group has reached consensus. In practice, however, the researcher frequently decides to end the process after two or three rounds, by which time firm trends have generally emerged.

This investigation did not start with an open-ended questionnaire but commenced with the issues identified in Watson's (1989) study. It was considered that the key concerns of South African IS executives would not be materially different from their American or Australian counterparts because of similarities in the business culture, IS environment, and the extensive infusion of American management technology into the South African corporate scene. In terms of size of economy and cultural background, it was also postulated that there are not radical differences between South African IS managers and their Australian counterparts. 
Two modifications were made to the methodology used in the MISRC's 1986 study. First, participants were asked to rate each issue, rather than identify and rank the top ten issues. Once a list of issues becomes large (beyond seven), the limited information processing capacity of humans (Miller, 1956) makes identification and ranking of issues a difficult task. Rating is far easier because the participants need consider only one issue at a time (Alreck and Setule, 1985). Second, unlike Watson's (1989) Australian study a mail survey was not used. All rounds of the Delphi process were conducted over ten days while the executives were in residence.

\section{Round one}

Thirty-seven delegates on an advanced IS executive programme at a university graduate school of business served as the sample. The issues of the Watson (1989) study were used as a basis for the first round questionnaire and were randomly arranged on the first round questionnaire. A full listing of the issues is shown as Appendix A. Participants were asked to consider what they perceived were the most critical issues facing them over the next three to five years and to indicate their views by rating each issue on the scale 1 to 10 , where 1 indicated the lowest priority issue and 10 indicated the highest priority issue.

Space was also provided for each manager to add new issues to the list, and participants were invited to modify the wording of any issue's rationale. As the sample were essentially captive, all 37 responded. Two new issues were identified (see Appendix B).

\section{Round two}

The second round questionnaire was designed so that each person could for each issue easily compare the average rating of participating IS executives and that person's first round rating. On the same line, the participant could enter a rating for round two. In round two, issues were listed in descending sequence on the basis of their average rating for round one, and new issues were listed at the end of the questionnaire.

\section{Round three}

The third round questionnaire had the same format as that of the second round. In round three, issues were

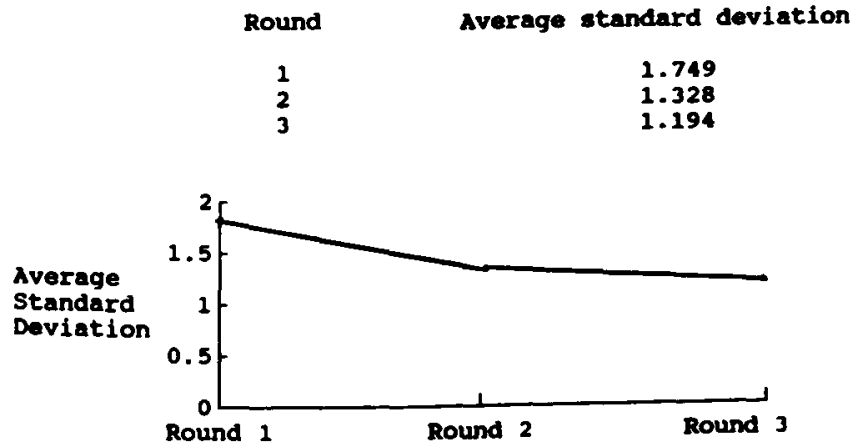

Figure 1 Average standard deviation of ratings for each round (based upon the 36 issues of the first round)
Table 1: The top ten issues

\begin{tabular}{|c|c|c|}
\hline Rank & Issue & Mean rating \\
\hline 1 & Improving IS strutegic planning & 8.94 \\
\hline 2 & $\begin{array}{l}\text { Using information systems for } \\
\text { competitive advantage }\end{array}$ & 8.64 \\
\hline 3 & $\begin{array}{l}\text { Increasing senior management's under- } \\
\text { standing of the role and contribution of IS }\end{array}$ & 8.28 \\
\hline 4 & $\begin{array}{l}\text { Assisting user management to identify and rank } \\
\text { opportumities for use of information technology }\end{array}$ & 8.25 \\
\hline 5 & $\begin{array}{l}\text { Specifying, recruiting and developing } \\
\text { IS human resources }\end{array}$ & 8.17 \\
\hline 6 & $\begin{array}{l}\text { Aligning the IS organization with } \\
\text { that of the enterprise }\end{array}$ & 8.11 \\
\hline 7 & $\begin{array}{l}\text { Facilitating and managing } \\
\text { end-user computing }\end{array}$ & 7.50 \\
\hline 8 & $\begin{array}{l}\text { Training of DP suff in various aspeas of } \\
\text { business which they are responsibie for supporting }\end{array}$ & 7.44 \\
\hline 9 & Developing an information architecture & 7.41 \\
\hline 10 & Improving information security and control & 7.33 \\
\hline
\end{tabular}

listed in descending sequence on the basis of their average rating for round two.

\section{Preliminary analysis}

The main purpose in using a Delphi study was to obtain consensus from IS executives as to their key concerns. Therefore, it is important to assess whether there was any convergence in opinion over the three rounds. The standard deviation of the ratings for an issue is a measure of consensus for that issue. Perfect agreement would give a standard deviation of zero. An overall measure of consensus for the questionnaire is the mean of the standard deviations for each issue, and this approach was used. As the introduction of new issues contaminates the measurement of consensus, the overall measure of consensus was based upon the 36 issues circulated in the first round. As Figure 1 illustrates, there was greater agreement in the third round compared with the first and second rounds. The third round, compared with the second, resulted in only a minor gain in consensus, as reflected by a slightly smaller average standard deviation, and it was therefore decided that the third round was an appropriate stopping point.

In Table 1 the top ten issues are listed in descending order of importance. Each is briefly discussed in relation to local and international trends.

\section{Discussion of key issues}

\section{Improving IS strategic planning}

Improving IS strategic planning is the number one concern. If the ratings are converted to rankings, we find that $20 \%$ of IS managers rank IS planning as their prime concern, and some $80 \%$ of managers rank IS planning in their top ten issues. Managers are beset by a number of problems that make IS planning a difficult task. Rapid changes in information technology; a South African business environment that is very exposed to the 
vagaries of the world economy; the emergence of enduser computing; competing methodologies for IS planning (Boynton and Zmud, 1987); the need for IS planning to relate to corporate goals; and the increasing dependence of organisations on information systems technology are all factors that make IS planning a number one concern.

In a survey of chief executives of 300 major South African companies, over $90 \%$ of the respondents agreed that it was essential to have a comprehensive plan for IS, integrated with the business plan (Baker \& Miller, 1984). However an in-depth study of several South African companies that had previously conducted extensive long range IS planning exercises revealed very mixed success for subsequent implementation of those plans (Miller, 1982, 1985).

\section{IS for competitive advantage}

The role of computers in organisations has expanded considerably since the early days of automation of clerical functions. Firms have entered the 'fourth era' of computing (Rockart, 1987) where IS is playing an active role in creating and sustaining competitive advantage (e.g. Wiseman, 1988). Most examples emanate from the United States and a study of 11 South African organisations reveals that the availability of systems to provide competitive advantage is very much less than that for traditional operational and managerial support systems. Even in large financial and retailing institutions, penetration of systems to enhance competitive thrust is classified as 'no use at all' or 'just starting' (Miller, 1989). However evidence is starting to accumulate of successful use of IS for competitive advantage in South Africa. Duffy and Assad list a number of examples (Duffy \& Assad, 1989) and Watson \& Pitt (1989) report case studies of South African wholesaling and retailing firms using information technology in logistics to gain competitive advantage. The high rating of this issue presages much future activity.

Increasing senior management's understanding of the role and contribution of IS

In the study referred to above, the firms that rated their IS function as most effective were also those that had achieved greater penetration of IS in the strategic and competitive areas (Miller, 1989). However, achievement of an effective IS function depends to a large extent on senior management's ability to identify the most important opportunities for IS and there is ample evidence that many senior managers, who formed their ideas about IS in the earlier eras of IS, see the role of IS in operational terms only. Thus it becomes vital to broaden the minds of senior management so that they may make informed judgements about the full potential of information systems and technology in their organisations. As Wiseman says,

'By viewing information technology through another lens, one discovers the new Strategic Information Systems world, and can explore it systematically for opportunities and threats.' (Wiseman, 1988: 50).

Assisting user management to identify and rank opportunities for the use of information technology

The high priority accorded this issue can also be related to the rapidly changing role of IS in organisations. Traditionally, potential cost saving was the basis for identifying IS opportunities. Ranking them was a simple matter of comparing payback periods or internal rates of return for competing projects. Those days are gone and there are now multiple criteria, many of them intangible that need to be weighed up to identify worthwhile opportunities and rank them. Yet Ginzberg (1978) suggested that companies typically home in on just one criterion (generally cost savings) when evaluating a particular opportunity and Dampney et al. (1984) found that reviewing systems to determine real benefits is uncommon and generally regarded as too difficult. (For a South African perspective see Lay (1988).) Currently socalled Critical Success Factors are a popular basis for identifying and ranking systems opportunities (e.g. Boynton \& Zmud, 1984) and recent research is underlining the importance of 'organisational fit' in achieving overall IS effectiveness (Miller, 1989). User managers need to be assisted in identifying the set of relevant criteria and incorporating them in rational procedures to select the most worthwhile opportunities.

\section{Specifying, recruiting and developing human resources}

The South African computer industry is chronically short of skilled personnel and this is reflected in the concern ranked fifth. The explosion in demand for informationtechnology solutions makes this a worldwide problem; to which must be added problems unique to South Africa. These include the 'brain drain' (helped along by political concerns, resistance to the draft, and a steady stream of advertisements offering job opportunities in the United States and Australia in particular), and structural peculiarities in the South African economy which have effectively excluded a large proportion of the workforce from skilled IS positions.

While major projects are underway to alleviate the situation (CUC, 1990), the human resources problem is likely to remain a major concem. Organisations will face a sellers' market for some time, and when they do find the elusive recruit, IS managers will discover that they lack the career planning knowledge to avoid that person simply becoming another turnover statistic.

\section{Aligning the IS organisation with that of the enterprise}

The level of the IS manager in the organisational hierarchy, his or her reporting line, and the centralisation or decentralisation of systems development and computer operations are all facets of the alignment issue. A 1984 survey of the largest computer users in South Africa revealed that half of all IS managers reported to the financial manager or director, while most of the others reported to other functional managers (Miller \& Baker, 1984). While there is some evidence that, 
especially in the financial services sector, IS managers are now tending to report at a higher level, this is a slow trend and in many organisations the IS department remains remote from the key decision-makers and inappropriately located in the organisation. This militates against the IS manager perceiving the true direction of the firm and its information needs.

\section{Facilitating and managing end-user computing}

In the last few years there has been an explosion in the direct use of computers by the end-user, occasioned by the falling price of personal computers and availability of powerful, easy-to-use software. Soon end-user computing (EUC) will consume more resources than traditional data processing (Panko, 1988). IS managers face a difficult task in balancing the needs to encourage and control this phenomenon. Encouragement is needed because of the manifest increase in productivity, particularly amongst knowledge workers, but control is necessary to avoid unnecessary duplication of effort and resources, poor documentation, inadequate data management, and lack of attention to security of information.

In a recent in-depth survey of 280 employees in a major international oil company, Ross (1989) identified six factors that appear to encompass end-user computing. These are: a company policy and strategy for EUC, EUC independence and competence, facilities and support for EUC, standardisation of hardware and software, the sharing and ease of use of EUC data and systems, and accuracy of data. This then is the territory for management of end-user computing.

The study also revealed that the characteristics of the individual user were more important predictors of effective usage than departmental characteristics, confirming international findings in a cross-cultural study of end-user computing (Ein-Dor \& Segev, 1989). Specifically the South African study found that the support for and participation in end-user computing by one's superior manager was a major predictor of individual end-user computing effectiveness. This is an important pointer to better facilitation of end-user computing.

Training of data processing (DP) staff in the various business aspects for which they are responsible

This issue was new to this survey, but once incorporated after the first round, rose quickly to top-ten status. The requirement for business training for IS staff addresses at least two issues. Firstly it is commonly recognised that many DP staff tend towards what Merton (1957) calls 'cosmopolitanism' (orientated towards their specialty) rather than 'localism' (orientated towards their company). This manifests itself in job-hopping. It is suggested that training in the business will foster localism. DP staff will develop a stronger company loyalty if they become partners with their users in understanding the business, rather than being limited to providing computer solutions.

Secondly, the trend towards strategic and competitive systems carries with it a trend towards much more complex systems requirements. Often users cannot define their needs accurately, and indeed such needs evolve over time. The more knowledgeable the IS staff are about the business, the more they can contribute in a dialogue about business opportunities. The effectiveness of this shift in IS-user communications has been welldocumented by Boland (1978).

\section{Developing an information architecture}

Developing an information architecture, a plan for representing the global information requirements of an organisation, is the ninth ranked issue. An information architecture is necessary if an organisation is to develop an integrated suite of applications and distribute applications to functional areas. However, there are many problems associated with the development of an information architecture (Brancheau and Wetherbe, 1985). The major reason for these problems is that the creation of an information architecture is a relatively unstructured task of broad scope, with few perceptible immediate benefits, that requires the participation of many individuals. Additional problems are: difficulty senior managers have in grasping conceptual models of an information architecture; production of an information architecture competes for resources that can be used to solve problems of a more immediate nature; and difficulty in translating an information architecture model into an application development plan.

\section{Improving information security and control}

In a survey of over 250 South African organisations, Gombay (1985) concluded that only 114 of these organisations were well-prepared to recover from a collapse of their physical or data facilities. Altogether 65\% of these firms would suffer significant business injury in such an event. Recently there has been much coverage of security issues in the popular press and there is anecdotal evidence that many more firms are evaluating the risks of security breaches, improving information security, and implementing disaster recovery plans. As firms place greater and greater reliance on central data bases, as they implement strategic systems that are woven into the mainstream business fabric, and as endusers take on more and more of the business analysis of computer data, the need for effective information security and control will bulk larger.

\section{Classification of Issues}

The top ten issues can be classified in terms of whether they focus on concerns internal or external to the IS domain, or as Hirschheim, Earl, Feeny and Locketl (1988) state, matters that are 'inside IS' and 'beyond IS'. In Table 2 is shown the four internal issues that deal with the functioning of the IS department emerging from this study: human resources, information architecture, information security and control and training IS staff in the business. However, the design of an information architecture and IS staff training have an external 
Table 2 Classification of top ten issues

\begin{tabular}{ll}
\hline Intemal orientation & Extemal orientation \\
\hline Human resources & IS strategic planning \\
Information architecture & IS for competitive advantage \\
Information security/contral & Senjor management under- \\
& standing of IS \\
Training IS staff in the business & User management ranking of \\
& IS opportunities \\
& Aligning IS with the enterprise \\
& End-user computing \\
\hline
\end{tabular}

element because they involve significant interaction with personnel outside the IS function. The remaining six issues shown are externally oriented as they deal with the relationship between IS and the enterprise.

It would appear that South African IS executives' major problems arise from the management of the interface between IS and the organisation. These findings are in accord with a study of ten leading UK IS executives conducted by Hirschheim et al. (1988), who found that the IS executives agreed that they spend the majority of their time on external tasks. Interestingly, these executives felt that in the future they would be focusing more auention on internal matters.

The current prominence of extemal issues implies that IS managers will have to spend more time outside the IS function to re-orient thinking towards exploiting IS for strategic advantage and aligning IS strategy with corporate directions (Hirschheim et al., 1988). In order to fulfill this role, the IS manager should have a general management perspective and be able to appreciate the viewpoint of other functional areas so that a clear understanding of the organisation's information systems needs is articulated. In those organisations where the IS manager cannot make this transition, it is likely that a replacement who has an enterprise orientation will be appointed to head up IS. The message is quite clear; external issues prevail, and IS management over the next few years will be based upon successful resolution of external concerns.

\section{Summary}

The purpose of this study was to indicate to IS managers the problems that their colleagues are facing and to alert those who serve the IS community as to where they should be directing their resources. While it is believed that the investigation is representative of the views of top South African IS managers, it should be remembered that a survey of this kind is a snapshot of opinion and changing circumstances can quickly alter IS managers' priorities. New issues, for example end-user computing, can emerge very quickly. The results should be used with caution and a careful watch maintained for emerging concerns.

Managers are most concerned with improving IS strategic planning, and there is certainly a need for further research and study in this area. Such work might provide answers as to why IS planning is a problem and lead to the development of methodologies to support more effective IS planning. Consultants need to improve or broaden their current products to satisfy client needs and could possibly benefit by more actively marketing their offerings in the IS planning area. Professional societies such as the Computer Society of South Africa and the Computer Users Council could foster interaction among IS managers and practitioners by sponsoring conferences or workshops on IS planning.

The human resources problem is perhaps more difficult to solve, and is likely to become more severe in the future because the South African education system clearly lacks the wherewithal to react effectively to market needs without a substantial increase in support from the South African government and business community. The solution is not to bemoan the problem but rather for organisations to take the initiative in the development of more, and more effective IS practitioners.

All top ten issues identified in this study address managerial problems with an emphasis on issues related to the interface between the IS function and the organisation. To be successful in this environment, the IS executive must manage the relationship between the IS department and the organisation and be prepared to spend more time operating outside the department than within it. In effect, the IS manager has to take an holistic perspective and see IS as something within the organisation, rather than see the organisation as something outside IS. Successful IS managers will make this transition and in so doing reduce the level of concern associated with many of the current issues.

\section{Acknowledgment}

The support of Debbie Stubbs who assisted with data collection and administration of the study, is gratefully acknowledged.

\section{Appendix B}

\section{Additional items incorporated in rounds 2 and 3}

Issue: Supplier relationships

Rationale: The viability of suppliers, and their ability to maintain continuity, especially in view of existing and possible sanctions will be fundamental to the IS manager.

Issue: Training of DP staff in various business aspects which they are responsible for supporting.

Rationale: While dp staff may be effective in very narrow area, it is essential that they gain a broader overview of the various functional areas of the business, such as marketing, production and finance.

\section{References}

Alreck, P.L. and Settle, R.B. 1985. The swruey research handbook. Homewood II: Richard Irwin.

Anon. 1987. Information technology planning in the 1990 's: directions for practice and research, MIS Quarterly, 11 (1), 59-72.

Baker R.F.R. and Miller, J. 1984. Computer based information systems in Soun Africa: A survey of executive 
perceptions, Working paper. Cape Town: Graduate School of Business, University of Cape Town.

Bass, B.M. 1983. Organizational decision making. Homewood II: Irwin.

Boland, R.J. 1978. The process and product of system design, Management Science, (24: 9), 887-898.

Boynton, A.C. and Zmud, R.W. 1984. An assessment of critical success factors, Sloan Management Review, Summer, 17-24.

Brancheau, J.C. and Wetherbe, J.C. 1987. Key issues in information systems management, MIS Quarterly; 11 (1), 23-45.

Brancheau, J.C. and Wetherbe, J.C. 1985. Information architecture: methods and practice. Minneapolis, MN: MIS Research Center, School of Management, University of Minnesota.

Computer Users' Council of South Africa, (CUC). 1989. Manpower project phase 1, Unpublished report.

Dampney, C.N.G., Hansell, A.E., Borthwick, K. and Gilmour, P. 1984. Directing information systems in an organisation: what is important and why? Proceedings of the Joint International Symposium on Information systems, Sydney, Australia. (241-260).

Dickson, G.W., Leitheiser, R.L., Wetherbe, J.C. and Nechis, M. 1984. Key information systems issues for the 1980's, MIS Quarterly, 8 (3), 135-148.

Duffy, N. and Assad, M.G. 1989. Information management: strategy formulation and implementation. Oxford: Oxford University Press.

Ein-Dor, P. and Segev, E. 1988. Intensity of end user computing. Working Paper 978, Tel Aviv University.

Ginzberg, M.J. 1979. Improving MIS project selection. Omega (7:6), 527-537.

Gombay, G.F. 1985. An appraisal of the dispositions taken by medium to large dala processing installations in South Africa to recover from a loss of their compuler facilities.

Unpublished technical report. Cape Town: University of Cape Town.

Hirschheim, R., Earl, M., Feeny, D. and Locketh, M. 1988. An exploration into the management of the information systems function: key issues and an evolutionary model. Information technology managemen' for productivity and competitive advantage. An IFIP TC-8 open conference, Singapore, 4.15-4.38.

Lay, P.M.Q. 1986. A partial-ordering framework for ranking information systems. De Ratione, Vol. 1. 2.

Merton, R.K. 1957. Social theory and social structure. New York: Free Press.

Miller, GA. 1956. The magical number seven, plus or minus two: some limits on our capacity for processing information. The Psychological Review, 63 (2), 81-97.

Miller, J. 1982. Factors influencing the success of companywide information systems planning. M.Comm thesis, University of Cape Town.

Miller, J. 1985. Information systems planning-principles and practice, South African Journal of Library and Information Science, 53, 4, 183-190.

Miller, J. 1989a. Information systems effectiveness and the fit between business needs and system capabilities. Proceedings of the Tenth Annual Intemational Conference on Information Systems, Boston, 273-288.

Miller, J. 1989b. The effectiveness of compuler-based information systems: Definition and measurement. Unpublished PhD thesis, University of Cape Town.

Panko, R.R. 1988. End user computing: management, opplications, and rechnology. New York: Wiley.

Rockart, J. 1988. The line takes the leadership - IS management in a wired society, Sloan Management Review. No. 57, Summer 1988.

Ross, M. 1989. Effectiveness of end user computing. Unpublished research report, Graduate School of Business, University of Cape Town.

Watson, R.T. 1989. Key issues in information systems management: An Australian perspective - 1988. Australian Computer Journal, August.

Watson, R.T. and Pitt, L.P. 1989. Competing with computers: An approach for the identification of areas of competitive advantage. S. Afr. J. Bus. Manage., Vol. 20, No. 4.

Wiseman, C. 1988. Strategic information systems. Homewood, II.6: Irwin.

\section{Appendix A}

\section{Round 1: Questionnaire}

\section{Key information systems management issues}

What do you consider to be the most critical issues facing IS executives over the next three to five years? Please indicate your views by rating each issue on the scale 1 to 10 , where 1 indicates a lowest priority issue and 10 indicates a highest priority issue. The more important the issue, the higher the score. Use the space below to assign your ratings. (Please feel free to change the wording of the issues or modify the rationale. Space is provided at the end of the form to write in additional issues.)

\begin{tabular}{ccc}
\hline $\begin{array}{c}\text { Average } \\
\text { rating } \\
\text { round } 1\end{array}$ & $\begin{array}{c}\text { Your rating } \\
\text { this round }\end{array}$ & Key issues and their rationale \\
\hline
\end{tabular}


ability to keep up with the information needs of its parent organisation. Computer personnel need to be recognized as people who can assist the organisation to grow. They have to develop the ability to identify with the employer.

Issue: Developing an information architecture.

Rationale: A corporate/global information architecture is needed to identify the major information categories used within an enterprise and their relationships to business processes. It is necessary to guide applications development and facilitate the sharing of dala. Issue: Aligning the IS organisation with that of the enterprise.

Rationale: The effectiveness with which IS can support the enterprise's information needs is dependent on the IS department's position within the enterprise. Too often IS is not located appropiately within the organisation. Issue: Improving the effectiveness of software development.

Rationale: The application development backlog remains unacceptably high levels. Users are getting impatient. Add to this the increasing costs of human recources and the need for improved effectiveness in systems development becomes clear.

Rationale: The proliferation of end-user computing through personal computers offers the promise of improved productivity but also the dangers of inadequate management control. Information systems management must balance control against the need for slack. Clarificaticn of IS and end-user roles is a necessity. Issue: Using information systems for competitive advantage.

Rationale: In many businesses, long-term survival is dependent upon using information systems to gain competitive advantage. The business can be lost without it. Competitive advantage results from recognition of opportunities through creativity and innovation, followed by rapid implementation. These are historical weaknesses of IS.

Issue: Increasing senior management's understanding of the role and contribution of IS.

Rationale: IS is often viewed by senior management as an overhead expense without appreciating new IS technologies in their entire operation. Business practices and organisational structures will need to be modified in many cases, and there needs to be a greater commitment by senior management to IS. IS also must demonstrate its own ability to leam and use technology to meet organisational goals.

Rationale: The organisation's data resources is growing in size, complexity and value. Despite this, it remains largely unrecognized, inaccessible, and underutilized. IS must develop a climate within its department and throughout the organisation which values the data resources as a corporate asset.

Rationale: Communication is the lifebond of the organisation. Using IS for competitive advantage often depends heavily on communications. Rapid and major changes in the industry complicate this task.

Issue: Facilitating organisational leaming and the use of IS techniques.

Rationale: Organisations that prosper will be those that make use of appropiate new IS technologies in their entire operation. Business practices and organisational structures will need to be modified in many cases. IS also must demonstrate its own ability to leam and use new technology.

Issue: Improving imformation security and control.

Rationale: As organisations increase their dependence on information systems, there is a greater risk from destruction and alteration of dats, disclosure to outside sources, and disruption of information services. Tight secure controls and fault tolerant information delivery are becoming a necessity.

Issue: Planning and managing the application portolio.

Rationale: The applications ponfolio is rapidly increasing in size, complexity, and maintenance cost. Despite the longevity of the maintenance problem, too liule is known abour managing it effectively.

Issue: Improving data integrity and quality assurance.

Rationale: Mainframe applications, timesharing extracts, and personal computer applications are all used to analyze data and prepare repons. Frequently there are discrepancies among these different data sources due to lack of controls in IS and user departments. Too often computer printouts are assurned to be accurate. Such assumptions can lead to faulty decisions.

Issue: Management skills of senior IS staff.

Rationale: Not enough auemion is paid to training managers with a technical background in basic people and management skills.

Issue: Enabling electronic dasa interchange and multi-vendor integration.

Rationale: Electronic communications with vendors and customers may offer tremendous competitive

advantage to a company. IS executives mua pash for basic industry standards. Standards would enable electronic dats interchange

and cost effective multi-vendor environments without major conversion costs or loss of functionality. 
computer. Some IS professionals are resisting this change. There is a teed to develop procedures for effective control of end-user computing.

Issue: Integrating data processing, office auxomation, and telecommunications.

Rationale: The capability now exists to incegrece systems that are based on these diverse tecturologies. As orzanisations try to integrate their tochnologies, orgenisations and managerial problems will need wo be solved.

Issue: Measuring IS effectiveness and productivity.

Rationale: The measurement of IS performance is crucial to its effective management. This is becoming more important as organisations invest more and more money in information systems.

Issue: Converting and using relational database management syseems.

Rationale: IBM is suggesting that it's major users convert to relational DEMS by 1990 . How? Is it really necessary for end-user applications? Can organisations afford the additional hardware and conversion coms? Too litule is known about this technology.

Issue: Ranking of development projects.

Rationale: Constraints on IS spending make it more difficult to recource many projects and there is a need for a method of effectively ranking potential projects.

Lssue: Developing and implementing docision support sysrems.

Rationale: Improving the effectiveness of managers is an impontant objective for information sysems. There has been much promised but too litule success in this area.

Issue: Operating the IS function as a business unit.

Rationale: The IS function should be self-funding and operate in a business environment.

Issue: Selecting and integrating peckaged application software.

Rationale: The changing relationship among costs of hardware, packaged software, and human resources makes managing this aspect of the business critical. Using purchased application software can cax costs, boost productivity, and increase user satisfaction, bex it can result in poor integration of systems and serious maintenance problems.

Issue: Establishing an effective chargeout system.

Rationale: The user pays concept needs to be effectively implemented to ensure thre IS spending is comiolled. Issue: Acquiring and using compuler-assisted sysems engineering software.

Rationale: To improve the productivity of IS professionals, computer systems are needed to support analysis, design and implementation activities.

Issue: Planning, implementing and managing office auromation.

Rationale: Office automation is being implemented by many organisutions to improve 'white collar' productivity. Problems arise in determining how this should be done and what the role of IS should be.

Issue: Determining appropriate IS funding levels.

Rationale: There is no generally accepted way of establishing the level of IS funding relative to the other funding needs of the organisation. This can pun both IS and general managers at a disadvantage.

Issue: Managing data and document storage.

Rationale: Information stored in boch electronic and handcopy form is accumulating at a staggering pace. There is a need to provide for future data and document storage requirements.

Issue: Making efffective use of computer graphics.

Rationale: Computer graphics offer an effective way to present information. Problems need wo be reatved in using graphics interactively and remotely, and integrating it with standard reporting mechanisms.

Issue: Managing the impact of artificial intelligence.

Rationale: Antificial intelligence may be the tool to integrate IS with other functions in the organisation. Its potential is not well understood. Although it is becoming increasingly feasible, too litule is known about managing this technology.

Issue: Planning, implementing and managing factor auromation.

Rationale: Factories are being automated to establish an intermationally competitive position. Many functions are involved - manufacturing, engineering, research and development, elc. Co-ordination of outomation efforts is critical. What should the rale of the IS department be? How should these new systems be integrated within themselves and within traditional IS applications?

Issue: Organisation of a corporate MIS department and subsidiary MIS depanments in each business unit. Rationale: In an organisation divided inso business units, it is difficult to maintain overall control of MS and at the same time allow each business unit the flexibility to provide its owm MIS services.

Issue: Assisting user management to identify and rank opportunities for the use of information tochnology. Rationale: User management are not fully aware of the potential of information technology to improve their unit's performance, and IS personnel do not understand the business well enough to recognize opportunities. There is a problem in malching the business of know-how of the users and IS specialists' knowledge so tha IS develops the high retum applications for users. 
the suitability of staff for this new enviromment. There is a need for a hybrid IS person i.e. programmer/analyst data base designer/communications specialist. Many existing staff do not have this combination of skills. Issue: Control of growth for both existing and new applications.

Rationale: IS management needs to ensure that growth in usage is constrained to planned limits and that new applications match the IS corporate databese plan.

$37 \quad$ A37

ADD ANY OTHER ISSUES AND RATIONALE HERE:

$38 \quad$ A38

Your name: 